\title{
Anti-Candida Activity and Chemical Composition of Cinnamomum zeylanicum Blume Essential Oil
}

\author{
Ricardo Dias de Castro ${ }^{1 *}$ and Edeltrudes Oliveira Lima ${ }^{2}$ \\ ${ }^{1}$ Programa de Pós Graduação em Odontologia; Universidade Federal da Paraíba; João Pessoa - PB - Brasil. \\ ${ }^{2}$ Programa de Pós Graduação em Produtos Naturais e Sintéticos Bioativos; Universidade Federal da Paraíba; \\ João Pessoa - PB - Brasil
}

\begin{abstract}
The purpose of this study was to identify the anti-Candida activity and chemical composition of the essential oil (EO) of Cinnamomum zeylanicum (cinnamon). For this, tests were conducted to determine the Minimum Inhibitory Concentration (MIC) and Minimum Fungicidal Concentration (MFC) and the action of C. zeylanicum EO on fungal cell wall of Candida albicans, C. tropicalis and C. krusei strains. The composition of the was analysed by gas chromatography with mass spectrometry. Significant antifungal activity of the EO was observed on the strains tested, with $87.5 \%$ and $62.5 \%$ of them sensitive, respectively at a MIC of $312.5 \mu \mathrm{g} / \mathrm{mL}$ and MFC of $2500 \mu \mathrm{g} / \mathrm{mL}$. In the presence of sorbitol, the MIC was $625 \mu \mathrm{g} / \mathrm{mL}$ against all the strains, showing a possible action of the EO on fungal cell wall. Eugenol (73.27\%) and trans- $\beta$-caryophyllene (5.38\%) were found in higher concentrations. The results indicated anti-Candida activity of the EO analyzed and suggested that it occurred due to the action on fungal cell wall.
\end{abstract}

Key words: Candidiasis, Cinnamomum zeylanicum, essential oils

\section{INTRODUCTION}

Candida species are opportunistic pathogens that inhabit the human body as commensal microorganisms and have been considered the major cause of fungal infections in humans. Usually, infections caused by Candida spp. are developed as a result of changes in immune response. The virulence of these fungi is attributed to their morphological plasticity, because depending on the growth conditions, they are capable to form hyphae, pseudohyphae and chlamydospores (Monge et al. 2006). These species are able to colonize skin surfaces and mucous membranes, especially genital areas, intestinal tract and oral cavity whose colonization is determined by ability to adhere to human tissues as well as to prosthetic devices and catheters (Donlan et al. 2001; Henriques 2004). Candida albicans is considered the most pathogenic Candida species. Nevertheless, a variety of other genus members such as $C$. tropicalis and C. krusei have been cited as agents responsible for the significant increase in the number of infections (Gilfillian et al. 1998).

One of the most important virulence factors of Candida species is their ability to form the biofilm, which has repercussions in the clinical context, because it is associated with increased resistance to antimicrobial agents (Mukherjee and Chandra 2004; Ramage et al. 2005; Henriques et al. 2006; Thein et al. 2006). Biofilms can be formed by a single microbial species, or a mixture of microorganisms, including fungi and bacteria.

*Author for correspondence: ricardodiasdecastro@yahoo.com.br 
Fungal species that have the ability to form the biofilms have been widely studied, especially as regards the action of antifungal agents (Bachmann et al. 2002; Kuhn et al. 2002; El-Azizi et al. 2004). Given the evident growth in the number of pathogens resistant to antibiotics currently used in the clinics, there is a clear and emerging need to introduce novel antimicrobial agents to the therapeutic arsenal (Khan et al. 2008). Concerning the resistance of Candida strains to azole synthetic antifungals (fluconazole, miconazole, itraconazole), several mechanisms contribute to the phenomenon of resistance, which include the overexpression, or mutation of ERG11 gene, which encodes the azole target enzyme, the lanosterol 14- $\alpha$-desmetilase (Marichal et al. 1999); overexpression of CDR and MDR genes that encode efflux pumps (Prasad et al. 1995; White et al. 1998); changes in ERG-3 gene that encodes $\Delta^{5.6}$ sterol desaturase enzyme, important in the synthesis of ergosterol (Howell et al. 1990), and changes in the lipid composition of the fungal plasma membrane, which hinders drug influx in the cell (Löffler et al. 2000). These mechanisms can occur simultaneously, contributing, therefore, to broaden the phenomenon of resistance.

Thus, naturally occurring products, especially those derived from the plant species, gain importance due to their availability and popular usage, which often ensures safety with regard to their toxicity. Among the plant species with therapeutic potential Cinnamomum zeylanicum Blume, popularly known as cinnamon is an important one. This species belongs to Lauraceae family, is native to Indonesia and cultivated in various regions of the world. Several biological properties of $C$. zeylanicum have been described such as antiseptic, analgesic, anti-spasmodic, astringent, insecticide and parasiticide properties (Moreira et al. 2007). Studies have shown that the essential oil obtained from its leaves has broad antimicrobial activity (Moreira et al. 2007; Khan et al. 2008). Therefore, the purpose of this study was to evaluate the anti-Candida activity and to identify the chemical composition of essential oil extracted from C. zeylanicum leaves.

\section{MATERIAL AND METHODS}

\section{Fungal Strains}

Srains of C. albicans ATCC 40277, C. albicans ATCC 40006, C. albicans MD 37, C. albicans
ICB 12, C. tropicalis ATCC 40042, C. tropicalis LM 759, C. krusei ATCC 40147 and C. krusei LM 120 were used in this study The inoculum was prepared in saline solution. Its turbidity was adjusted in accordance with McFarland scale (0.5), which was equivalent to the absorbance of 0.08 0.10 at $625 \mathrm{~nm}$ corresponding to $5 \times 10^{6} \mathrm{CFU} / \mathrm{mL}$.

\section{Essential Oil}

The essential oil of $C$. zeylanicum, whose antifungal activity and chemical composition was evaluated, was obtained from Ferquima Ind. and Com. Ltd (Vargem Grande Paulista, São Paulo, Brazil). Its physical and chemical parameters were described by the supplier. The emulsion of essential oil was obtained according to Allegrini et al. (1973) by mixing $0.4 \mathrm{~mL}$ of essential oil, 0.04 $\mathrm{mL}$ of TWEEN 80 and q.s. (quantum sufficit) 5.0 $\mathrm{mL}$ of sterile distilled water. This mixture was vortexed for five minutes.

\section{Determination of Minimum Inhibitory Concentration (MIC)}

The MIC of the essential oil was determined through the microdilution technique proposed by Ellof (1998). For this, $100 \mu \mathrm{L}$ of Sabouraud dextrose broth (SDB) $\left(\right.$ Difco $\left.^{\circledR}\right)$ doubly concentrated was taken into the microdilution plate wells. Then, $100 \mu \mathrm{L}$ of the emulsion of essential oil were distributed at an initial concentration of $5,000 \mu \mathrm{g} / \mathrm{mL}$. From this concentration, serial dilutions were made by withdrawing an aliquot of $100 \mu \mathrm{L}$ from the most concentrated well and inserting it into the following well. In each well of the column, aliquots of $10 \mu \mathrm{L}$ of the inoculum were dispensed for each strain tested. In parallel, a control was run for the viability of the yeast strains under study and control of strain sensitivity for the antifungal effect of nystatin (Sigma-Aldrich ${ }^{\circledR}$ ) and miconazole (Sigma-Aldrich ${ }^{\circledR}$ ), both at 1024 $\mu \mathrm{g} / \mathrm{mL}$, which have been considered standards in clinical use by the microdilution technique.

Tests were performed in triplicate and plates were incubated at $35^{\circ} \mathrm{C}$ for $24-48 \mathrm{~h}$. The readings for the determination of essential oil MIC on the yeast strains was made by the visual method. The formation of cells clusters ("button") at the bottom of the well was taken into consideration. The lowest concentration of the product under test capable to produce visible inhibition on the growth of yeast strains used in microbiological assays was considered as MIC. To confirm the presence of 
viable microorganisms at non-inhibitory concentrations, $10 \mu \mathrm{L}$ of the dye 2,3,5 triphenyl tetrazolium chloride in each well was added, which reflected the activity of dehydrogenase enzymes involved in the process of breathing.

\section{Determination of Minimum Fungicidal Concentration (MFC)}

After determining the MIC, the inhibitory and two following higher concentrations as well as the positive controls were subcultured on Sabouraud dextrose $\left(\right.$ Difco $\left.^{\circledR}\right)$ agar plates in triplicate. After 24 $h$ of incubation at $30^{\circ} \mathrm{C}$, the readings of MFCs were carried out based on growth controls and the MFC was the lowest drug concentration that hindered visible growth of the subculture.

\section{Action of $C$. zeylanicum Essential Oil on the Fungal Cell Wall}

The MIC of $C$. zeylanicum essential oil in the presence of sorbitol $(0.8 \mathrm{M})$ was determined in triplicate by microdilution using 96 -well U-bottom microtiter plates (ALAMAR ${ }^{\circledR}$ ). In each well, 100 $\mu \mathrm{L}$ of SDB (Difco ${ }^{\circledR}$ ) medium was added, which was previously supplemented with sorbitol presenting molecular weight of $132.17 \mathrm{~g}$ (VETEC Química Fina Ltda - Rio de Janeiro/RJ), both doubly concentrated. Subsequently, $100 \mu \mathrm{L}$ of the emulsion of essential oil, also doubly concentrated, were dispensed into the wells in the first row of the plate. Then through a serial dilution at a ratio of two, concentrations ranging from 10,000 to $10 \mu \mathrm{L} / \mathrm{mL}$ of essential oil and, in relation to sorbitol, a final concentration of $0.8 \mathrm{M}$ in each well were obtained. Finally, $10 \mu \mathrm{L}$ of inoculum was added into the wells, where each column of the plate corresponded to a fungal strain specifically.

A control of microorganism was performed by placing $100 \mu \mathrm{L}$ of the same SDB and sorbitol $(0.8$
M) also doubly concentrated, $100 \mu \mathrm{L}$ of sterile distilled water and $10 \mu \mathrm{L}$ of inoculum of each species. In order to verify the lack of interference on the results due to the solvent used when preparing the emulsion (Tween 80 , in this case), a control was performed in which $100 \mu \mathrm{L}$ of the same SDB and sorbitol $(0.8 \mathrm{M})$ also doubly concentrated, $100 \mu \mathrm{L}$ of Tween 80 (10\% in sterile distilled water) and $10 \mu \mathrm{L}$ of suspension were added. A sterility control was also conducted, where $200 \mu \mathrm{L}$ of SDB were placed in a well without the fungi suspension. The microplates were sowed and incubated at $37^{\circ} \mathrm{C}$ for $48 \mathrm{~h}$ to accomplish the reading (Frost et al. 1995).

\section{Chemical Analysis of the Essential Oil}

The analysis of C. zeylanicum essential oil was performed by gas chromatography with mass spectrometry (CG-EM) using QP-5050A with a GC-17A (Shimadzu, Japan); HP-5 capillary column $(25 \mathrm{~mm} \quad \mathrm{x} \quad 0.2 \mathrm{~mm} \quad \mathrm{x} \quad 0.33 \mathrm{~mm})$; temperatures: injector $\left(220^{\circ} \mathrm{C}\right)$, detector $\left(280^{\circ} \mathrm{C}\right)$, column $\left(60^{\circ} \mathrm{C}\right), \quad 3^{\circ} \mathrm{C} \min ^{-1}, \quad 240^{\circ} \mathrm{C} \quad(7 \mathrm{~min})$; flow rate of carrier gas (highly dried $\mathrm{He}$ ) of 1.0 mL. $\min ^{-1}$ (Adams 1995; McLafferty and Stauffer 1996).

\section{RESULTS AND DISCUSSION}

All the tested strains were sensitive to the essential oil obtained from the leaves of $C$. zeylanicum (Table 1), with MIC values ranging between 312.5 and $625 \mu \mathrm{g} / \mathrm{mL}$. A total of $87.5 \%$ of Candida strains were sensitive to the concentration of 312.5 $\mu \mathrm{g} / \mathrm{mL}$. The MFC was $2500 \mu \mathrm{g} / \mathrm{mL}$ for $62.5 \%$ of the strains tested. The strains of $C$. albicans ICB 12 and $C$. tropicalis LM 759 were among the most sensitive (MFC: $625 \mu \mathrm{g} / \mathrm{mL}$ ) (Table 1).

Table 1 - Minimum Inhibitory Concentration (MIC) and Minimal Fungicidal Concentration (MFC) of $C$. zeylanicum essential oil, nystatin and miconazole on Candida strains.

\begin{tabular}{lcccccc}
\hline \multirow{2}{*}{ Strains } & \multicolumn{2}{c}{ C. zeylanicum } & \multicolumn{2}{c}{ Nystatin } & \multicolumn{2}{c}{ Miconazole } \\
\cline { 2 - 6 } & $\begin{array}{c}\text { MIC } \\
(\boldsymbol{\mu g} / \mathbf{m L})\end{array}$ & $\begin{array}{c}\text { MFC } \\
(\boldsymbol{\mu g} / \mathbf{m L})\end{array}$ & $\begin{array}{c}\text { MIC } \\
(\boldsymbol{\mu} \mathbf{g} / \mathbf{m L})\end{array}$ & $\begin{array}{c}\text { MFC } \\
(\boldsymbol{\mu g} / \mathbf{m L})\end{array}$ & $\begin{array}{c}\text { MIC } \\
(\boldsymbol{\mu} \mathbf{g} / \mathbf{m L})\end{array}$ & $\begin{array}{c}\text { MFC } \\
(\boldsymbol{\mu g} / \mathbf{m L})\end{array}$ \\
\hline C. albicans ATCC 40277 & 312.5 & 2500 & 32 & 64 & 32 & 32 \\
C. albicans MD 37 & 312.5 & 2500 & 64 & 64 & 8 & 32 \\
C. albicans ICB 12 & 625 & 625 & 64 & 64 & 32 & 32 \\
C. albicans LM 42V & 312.5 & 1250 & 64 & 64 & 32 & 32 \\
C. tropicalis ATCC 40042 & 312.5 & 2500 & 64 & 64 & 32 & 32 \\
C. tropicalis LM 759 & 312.5 & 625 & 64 & 64 & 32 & 32 \\
C. krusei ATCC 40147 & 312.5 & 2500 & 64 & 64 & 16 & 32 \\
C. krusei LM 120 & 312.5 & 2500 & 64 & 64 & 32 & 32 \\
\hline
\end{tabular}


These results were similar to those described by Klan et al. (2008). Through the test of diffusion in solid medium, they found halos of growth inhibition for the strains of $C$. albicans isolated from the clinical infections larger than $40 \mathrm{~mm}$ and MIC of $780 \mu \mathrm{g} / \mathrm{mL}$. Quale et al. (1996) evaluated the antifungal activity of essential oil of $C$. zeylanicum on Candida strains resistant to fluconazole. They found MIC values of $C$. zeylanicum ranging between 50 and 30,000 $\mu \mathrm{g} / \mathrm{mL}$. Hili et al. (1997) showed that $72.2 \%$ of the strains of $C$. albicans were sensitive to the essential oil of $C$. zeylanicum at $500 \mu \mathrm{g} / \mathrm{mL}$. Pozzatti et al. (2008) evaluated the susceptibility to C. zeylanicum essential oil of 138 strains of Candida, including C. albicans, C. tropicalis and C. krusei, and MIC values ranged between 200 and $1600 \mu \mathrm{g} / \mathrm{mL}$. However, most strains required $1600 \mu \mathrm{g} / \mathrm{mL}$. For MFC, variations were observed between 800 and $1800 \mu \mathrm{g} / \mathrm{mL}$.

Nystatin and miconazole, synthetic antifungal agents used as controls, showed MIC values of 64 and $32 \mu \mathrm{g} / \mathrm{mL}$, respectively on 87.5 and $75 \%$ of Candida strains. These antifungal agents have been used as reference for the treatment of superficial fungal infections caused by Candida species. Miconazole is a representative for the azole antifungals whose mechanism of action consists in inhibiting the synthesis of ergosterol is by binding to the enzyme lanosterol 14- $\alpha$ demethylase, causing changes in the fungal cytoplasmic membrane and then hindering fungal development (Chen and Sobel 2005). Alves and
Cury (1992) evaluated the susceptibility to the antifungal nystatin of strains of $C$. albicans, $C$. tropicalis, C. krusei and found MIC and MFC values ranging respectively from 0.5 to $8 \mu \mathrm{g} / \mathrm{mL}$ and 8 to $64 \mu \mathrm{g} / \mathrm{mL}$. Wingeter et al. (2007) assessed the sensitivity of $C$. albicans strains and Candida non-albicans isolated from the patients with denture stomatitis. They observed MIC values between 2 and $64 \mu \mathrm{g} / \mathrm{mL}$. These findings were similar to those found in this study, in which for nystatin MIC values ranged from 32 to $64 \mu \mathrm{g} / \mathrm{mL}$ and MFC of $64 \mu \mathrm{g} / \mathrm{mL}$.

In relation to miconazole, Batista et al. (1999) found MIC values between 0.8 and $2 \mu \mathrm{g} / \mathrm{mL}$ on 16 strains of $C$. albicans. The MFC showed wide variations $(2.51$ to $64 \mu \mathrm{g} / \mathrm{mL})$. This study found that miconazole had MFC of $32 \mu \mathrm{g} / \mathrm{mL}$ on all strains tested.

Table 2 shows the MIC values of $C$. zeynalicum essential oil in the presence and absence of $0.8 \mathrm{M}$ sorbitol osmotic protector. As evident, sorbitol protected the cells from the inhibitory effects of essential oil, since there were changes in the MIC values of the product analyzed against all the strains tested. The control with sorbitol ensured the reliability of the results and methodology since the strains were able to grow in the presence of sorbitol and lack of essential oil evaluated. These results suggested that the antifungal activity of essential oil of C. zeylanicum somehow involved its direct interaction with the cell wall of yeasts under study.

Table 2 - Action of the essential oil of C. zeylanicum on the fungal cell wall.

\begin{tabular}{lcccc}
\hline \multirow{2}{*}{ Strains } & $\begin{array}{c}\text { MIC }- \text { without } \\
\text { Sorbitol }(\boldsymbol{\mu g} / \mathbf{m L})\end{array}$ & $\begin{array}{c}\text { MIC }- \text { with } \\
\text { sorbitol }(\boldsymbol{\mu g} / \mathbf{m L})\end{array}$ & \multicolumn{2}{c}{ Controls } \\
\cline { 3 - 5 } C. albicans ATCC 40277 & 312,5 & 625 & Sorbitol & Sterility \\
C. albicans MD 37 & 312,5 & 625 & + & - \\
C. albicans ICB 12 & 625 & 625 & + & - \\
C. albicans LM 42V & 312,5 & 625 & + & - \\
C. tropicalis ATCC 40042 & 312,5 & 625 & + & - \\
C. tropicalis LM 759 & 312,5 & 625 & + & - \\
C. krusei ATCC 40147 & 312,5 & 625 & + & - \\
C. krusei LM 120 & 312,5 & 625 & + & - \\
\hline + presence of strain growth & & & &
\end{tabular}

The test with sorbitol performed in this study was based on the extent of damage that products with antifungal activity produced on the fungal cell wall components. If the product acted somehow on the fungal cell wall, it would cause cell lysis in the absence of an osmotic stabilizer. Thus, this test compared the MIC of antifungal products in the absence and presence of $0.8 \mathrm{M}$ sorbitol, an osmotic protector used to stabilize the fungal protoplasts (Pereira 2009). The protection with 
sorbitol is a test that has a broad spectrum of possibilities, since it allows to detect not only agents that interfere with the synthesis of cell wall polymers and its vicinity, but also the regulatory mechanisms involved in these processes that complement each other as microscopic observation of malformations detected in fungal strains analyzed previously (Lesage and Bussey 2006). Thus, the results of this study suggested further investigation of the action of $C$. zeylanicum essential oil on fungal micromorphology. The chemical composition of essential oil from the leaves of $C$. zeylanicum is hown in Table 3.

Table 3 - Chemical characterization of C. zeylanicum leaf essential oil.

\begin{tabular}{cclccc}
\hline Peaks & $\begin{array}{c}\text { Retention time } \\
(\mathbf{m i n})\end{array}$ & \multicolumn{1}{c}{ Compound } & $\begin{array}{c}\text { \% in the } \\
\text { formulation }\end{array}$ & $\begin{array}{c}\text { Molecular } \\
\text { weight }\end{array}$ & $\begin{array}{c}\text { Charge/mass } \\
\text { Relation }\end{array}$ \\
\hline 1 & 5.644 & $\alpha$-pinene & 1.31 & 136 & 93.15 \\
2 & 6.017 & Camphene & 0.45 & 136 & 93.10 \\
3 & 6.218 & Benzaldehyde & 0.25 & 106 & 77.10 \\
4 & 6.792 & $\beta$-pinene & 0.48 & 136 & 93.10 \\
5 & 7.641 & $\alpha-$-hellandrene & 1.29 & 136 & 93.15 \\
6 & 8.293 & p-cymene & 1.24 & 134 & 119.15 \\
7 & 8.471 & $\beta$-phellandrene & 1.57 & 136 & 93.10 \\
8 & 11.164 & Linalool & 3.31 & 136 & 71.10 \\
9 & 14.217 & 4-terpineol & 0.12 & 154 & 71.10 \\
10 & 19.133 & Safron & 1.76 & 162 & 162.15 \\
11 & 23.633 & Eugenol & 73.27 & 164 & 164.15 \\
12 & 25.217 & Trans- $\beta$-caryophyllene & 5.38 & 204 & 41.05 \\
13 & 26.133 & Cinnamic alcohol acetate & 2.53 & 176 & 43.00 \\
14 & 26.498 & $\alpha$-humulene & 1.01 & 204 & 93.10 \\
15 & 29.511 & Eugenol acetate & 1.06 & 206 & 164.15 \\
16 & 31.708 & Caryophyllene oxide & 0.92 & 177 & 43.05 \\
17 & 38.655 & Benzyl benzoate & 4.04 & 212 & 105.10 \\
\hline
\end{tabular}

C. zeylanicum is a plant that has significant amount of essential oil in its leaves. This oil is quoted as having more than 72 substances (Semanayke et al. 1978). As shown in Table 3, GC-MS analysis resulted in identification of 17 components. Among the phytochemicals, eugenol was presented as the major component, accounting for $73.27 \%$ of the constituents, followed by trans$\beta$-caryophyllene $(5.38 \%)$ and benzyl benzoate (4.04\%). These results confirmed those of previous reports, reporting eugenol as the main component of $C$. zeylanicum essential oil (Semanayke et al. 1978; Pozzatti et al. 2008). It is noteworthy that despite all the organs of a plant can accumulate essential oils, their chemical composition, physico-chemical characteristics and odor can vary according to the location. Although genetically controlled, biosynthesis of the constituents of a plant is strongly affected by the environment, harvesting and post harvest, rainfall, temperature, light and humidity (Sharmar and Tripathi 2006). Eugenol belongs to a group of essential oil constituents originated from the reduction of the side chain of cinnamic acids, which are derived from phenylalanine. These compounds are also present in Syzygium aromaticum (clove), Pimpinella anisum (aniseed), Foeniculum vulgare (fennel) and Illicium verum (star anise-) (Rastogi et al. 2008).

This study is the pioneer in investigating a possible effect of essential oil from C. zeylanicum leaves on cell wall of Candida strains. From the results obtained, it was concluded that $C$. zeylanicum essential oil could be a promising product for the treatment of fungal infections caused by Candida spp. Nonetheless, further microbiological tests and pre-clinical studies are suggested to effectively elucidate the efficacy of this product in treating candidiasis.

\section{CONCLUSION}

The analysis of antifungal activity of $C$. zeylanicum essential oil showed that (i) it had action on the strains of $C$. albicans, $C$. tropicalis and $C$. krusei; (ii) this activity was probably by the action of essential oil in the process of fungal cell 
wall synthesis, and (iii) eugenol was the major phytochemical component.

\section{REFERENCES}

Adams RP. Identification of essential oil components by gas chromatography/mass spectroscopy. Carol Stream, Illinois: Allured Publishing Corporation, 1995.

Allegrini J, Bouchberg MS, Maillols H. Émulsions d'huiles essencielles, fabrication et applications en microbiogie. Soc Phamc Montp. 1973; 33: 86.

Alves SH, Cury AE. Candida from câncer patients: susceptibility in vitro to polyene antifungal agents. Rev Insti Med Trop. 1992; 34: 251-254.

Bachmann SP, Walle KV, Ramage G, Patterson TF, Wickes BL, Graybill JR, López-Ribot JL. In vitro activity of caspofungin against Candida albicans biofilms. Antimicrob. Agents Chemother. 2002; 46: 3591-3596.

Batista JM, Birman EG, Cury AE. Susceptibility to antifungal drugs of Candida albicans strains isolated from patients with denture stomatitis Rev Odontol Univ São Paulo. 1999; 13: 343-348.

Chen A, Sobel JD. Emerging azole antifungal. Expert Opin Emerg Drugs 2005; 10:21-33.

Donlan RM. Biofilms and device-associated infections. Emerg Infect Dis. 2001; 7: 277-281.

El-Azizi MA, Starks SE, Khardori N. Interactions of Candida albicans with other Candida spp. and bacteria in the biofilms. J Appl Microbiol. 2004; 96: 1067-1073.

Ellof JN. A sensitive and quick microplate method to determine the minimal inhibitory concentration of plant extracts for bacteria. Planta Med. 1998; 64: 711-713.

Frost DJ, Brandt KD, Cugier D, Goldman R. A wholecell Candida albicans assay for the detection of inhibitors towards fungal cell wall synthesis and assembly. J Antibiotic. 1995; 28: 306-309.

Gilfillian, D, Sullivan, J, Haynes, K, Parkinson T, Coleman DC, Gow NAR. Candida dubliniensis: phylogeny and putative virulence factors. Microbiol. 1998; 144: 829-838.

Henriques M, Azeredo J, Oliveira R. Candida albicans and Candida dubliniensis: comparison of biofilm formation in terms of biomass and activity. $\mathrm{Br} J$ Biomed Sci. 2006; 63: 5-11.

Henriques M, Azeredo J, Oliveira R. Adhesion of Candida albicans and Candida dubliniensis to acrylic and hydroxyapatite. Colloids Surf B 2004; 33: 235241.

Hili P, Evans CS, Veness RG. Antimicrobial action of essential oils : the effect of dimethylsulphoxide on the activity of cinnamon oil. Lett Appl Microbiol. 1997; 24: $269-275$.
Howell SA, Mallet AI, Noble WC. A comparison of the sterol content of multiple isolates of the Candida albicans Darlington strain with other clinically azolesensitive and -resistant strains. J Appl Microbiol. 1990; 69: 692-696.

Khan R, Islam B, Akram M, Shakil S, Ahmad AA, Ali SM, Siddiqui M, Khan AU. Antimicrobial activity of five herbal extracts against multi drug resistant (MRD) strains of bacteria and fungus of clinical origin. Molecules. 2008; 13: 1-12.

Kuhn DM, Chandra J, Mukherjee PK, Ghannoum MA. Antifungal susceptibility of Candida biofilms: unique efficacy of amphotericin B lipid formulations and echinocandins. Antimicrob Agents Chemother. 2002; 46: 1773-1780.

Lesage G, Bussey H. Cell wall assembly in Saccharomyces cerevisiae. Microbiol Mol Biol Res. 2006; 70: 317-343.

Löffler J, Einsele H, Hebert H. Phospholipid and sterol analysis of plasma membranes of azole-resistant Candida albicans strains. FEMS Microbiol Lett. 2000; 185: 59-63.

Marichal P, Koymans L, Willemsens S, Bellens D, Verhasselt P, Luyten W, Borges M, Ramaekers FCS, Odds F, Bossche HV. Contribution of mutations in the cytochrome P450 14 $\alpha$-demethylase (Erg11p, Cyp51p) to azole resistance in Candida albicans. Microbiol. 1999; 145: 2701-2713.

McLafferty FW, Stauffer D. The wiley/NBS registry of mass spectral data. New York: John Wiley Sons, 1989.

Monge RA, Roma'n E, Nombela C, Pla J. The MAP Kinase signal transduction network in Candida albicans. Microbiol. 2006; 152: 905-912.

Moreira ACP, Lima EO, Souza EL, Dingenen MAU, Trajano VT. Inhibitory effect of Cinnamomum zeylanicum Blume (Lauraceae) essential Oil and betapinene on the growth of dematiaceous moulds. Braz J Microbiol. 2007; 38: 33-38.

Mukherjee PK, Chandra J. Candida biofilm resistance. Drug Resist Update. 2004; 7: 301-309.

Pereira FO. Antifungal activity of the essential oil of Cymbopogon winterianus Jowitt ex Bor on dermatophytes of the genus Trichophyton. [Dissertation]. João Pessoa, Brazil: Federal University of Paraiba; 2009.

Pozzatti P, Scheid LA, Spader TB, Atayde ML, Santurio JM, Alves SH. In vitro activity of essential oils extracted from plants used as spices against fluconazole-resistant and fluconazole-susceptible Candida spp. Can J Microbiol. 2008; 54: 950-956.

Prasad R, Wergifosse P, Goffeau A, Balzi E. Molecular cloning and characterization of a novel gene of Candida albicans, CDR1, conferring multiple resistance to drugs and antifungals. Curr Genet. 1995; $27: 320-329$. 
Quale JM, Landman D, Zaman MM, Burney S, Sathe SS. In vitro activity of Cinnamomum zeylanicum against azole resistant and sensitive Candida species and a pilot study of cinnamon for oral candidiasis. Am J Chin Med. 1996; 24: 103-109.

Ramage G, Saville SP, Thomas DP, Lo'pez-Ribot JL. Candida biofilms: an update. Eukaryot Cell. 2005; 4: 633-638.

Rastogi N, Domadia P, Shetty S, Dasgupta D. Screening of natural phenolic compounds for potential inhibit bacterial cell division protein FtsZ. Indian J Exp Biol. 2008; 46: 783-787.

Senanayake UM, Lee TH, Wills RBH. Volatile constituents of cinnamon (Cinnamomum zeylanicum) oils. J Agric Food Chem. 1978; 26: 822-824.

Sharmar N, Tripathi A. Effects of Citrus sinensis (L.) Osbeck epicarp essential oil on growth and morphogenesis of Aspergillus niger (L.) Van Tieghem. Microbiol Res. 2006; 163: 337-344.
Thein ZM, Samaranayake YH, Samaranayake LP. Effect of oral bacteria on growth and survival of Candida albicans biofilms. Arch Oral Biol. 2006; 51: 672-680.

White TC, Marr KA, Bowden RA. Clinical, cellular, and molecular factors that contribute to antifungal drug resistance. Clin Microbiol Rev. 1998; 11: 382492.

Wingeter MA, Guilhermetti E, Shinobu CS, Takaki I, Suidzinski TIE. Microbiological identification and in vitro sensitivity of Candida isolates from the oral cavity of HIV positive individuals. Rev Inst Med Trop. 2007; 40: 272-276.

Received: May 08, 2012; Accepted: July 10, 2013. 